\title{
Fetal Cells May Produce Microbes
}

\author{
Alen J Salerian MD* \\ Organisation Modern Psychiatry, Greece
}

Received: 此: September 03, 2018; Published: 制 September 14, 2018

*Corresponding author: Alen J Salerian MD, Organisation Modern Psychiatry, Zaimi street, paleo falero, Athens 17562, Greece

\begin{abstract}
Background: A plethora of evidence suggest pathways independent of contamination may produce microbial growth and infections.

Objective: To prove that fetal cells may produce microbes.

Methods: We searched the keywords fetal infections in Google scholar and pub med for articles and their references published in English from 2000 to 2017. We then applied the probability theory to calculate the probability of pathways independent of contamination to produce fetal infections.
\end{abstract}

Results: Fetal cells may produce infections. The probability of certainty of this observation is $99.9998 \%$.

Conclusion: Fetal cells may produce infections.

Keywords: Germ Theory; Infections; Gastric Ulcers; Duodenal Ulcers; Burn Wounds Infections

\section{Introduction}

Unicellular organisms (prokaryota) including bacteria transformed from lifeless matter 3.5 billion years ago [1-5]. Organic compounds were produced by artificial methods [6]. Microorganisms transform to other microorganisms [7]. Human cells transform to different cells [8,9]. A lifeless protein transforms to an infectious prion [10]. All of the above data suggest pathways independent of contamination may produce microbes.

\section{Objective}

To prove that fetal cells may produce microbes.

\section{Methods}

We searched the keywords fetal infections in Google scholar and pub med for articles and their references published in English from 2000 to 2017 . We then applied the probability theory to calculate the probability of pathways independent of contamination to produce fetal infections.

\section{Results}

\section{Evidence Consistent with Fetal Cells May Produce Microbes}

A plethora of evidence suggest normal flora may come from trans formation of human cells consistent with the observations that the amniotic fluid, placenta, milk of healthy neonates is not sterile [11-14].

\section{Mathematical Evidence: Fetal Cells May Produce Microbes}

The probability of a physically possible observation to be correct exponentially increases by each supporting evidence and can be expressed as an equation: $\mathrm{C}=100-1 / 2 \mathrm{n}$ ("C "representing the percent probability of certainty and "n "representing the number of diverse evidence consistent with the observation).

This equation is based upon the premise that each supporting evidence or observation is a hypotheses -a logical inference from observing facts from which consequences may be deduced -with a \% 50 chance of being correct and therefore the final outcome would be the same as the probability of random occurrence in flipping a coin. Hence it would be like "heads"coming up a consecutive number " $n$ " of times. For instance, the probability of "heads"coming up 3 consecutive times is $1 / 23$ or $1 / 8$ or $11 \%, 10$ consecutive times is $1 / 210$ or $\% 0.09$.

Of crucial significance, consistent with the framework of flipping a coin, potential flaws of statistical analysis - randomness and bias- have no effect on the accuracy of final outcome. As long as it is fair play without tricks it does not matter who flips the coin. 
Table 1:

\begin{tabular}{|c|}
\hline Fetal Cells May Produce Microbes: C=100 -1/2 $2^{17}=099.9996$ \\
\hline Organic compounds were produced by artificial methods. \\
\hline A lifeless protein transforms to an infectious prion. \\
\hline Microorganisms transform to other microorganisms. \\
\hline Human cells transform to different cells \\
\hline Lifeless organic matter of earth transformed to microbesN. \\
\hline Amniotic fluid is not sterile. \\
\hline Meconium is not sterile. \\
\hline Human milk is not sterile. \\
\hline Placenta is not sterile. \\
\hline Tinea versicolor infections are not contagious $[15,16]$. \\
\hline Inoculation of tinea versicolor pathogens do not cause infections without occlusion $[17,18]$. \\
\hline Epidemiological data suggest $\mathrm{H}$ pylori-gastric ulcer infections are not transmitted from host to host [19]. \\
\hline $\begin{array}{l}\text { Sterile burn wounds vigorously treated with antibiotics in burn units with excellent infection prevention almost always develop microbial growth and } \\
\text { infections }[20,21] .\end{array}$ \\
\hline $\begin{array}{l}\text { Sterile burn wounds vigorously treated with antibiotics in burn units with excellent infection often develop infections by Pseudomonas aeruginosa } \\
\text { PA01, an opportunistic pathogen with morphological features [ large genome size, greater functional complexity and the younger evolutionary age] } \\
\text { very different than normal bacteria [20,21]. }\end{array}$ \\
\hline Bacteria exist in extraordinarily remote locations on earth [22]. \\
\hline Theory of evolution [23]. \\
\hline
\end{tabular}

The probability that Fetal Cells May Produce Microbes is \% 99.9996 (Table 1) [15-23].

\section{Discussion}

Although, the precise mechanism and pathways of transformation remain unknown the probability that fetal cells produce or transform to microorganisms to be correctis $99.9996 \%$. The presence of microorganisms in placenta or amniotic fluid has been attributed to contamination by gut microbiota. This observation has never been validated. Furthermore, the possibility of contamination through various barriers of human tissue does not seem to be likely. Of importance, milk microbiota are morphologically distinct and are not contaminants. This discovery may introduce novel treatments for opportunistic infections especially those associated with burns and major trauma. It may improve our understanding of inflammatory disorders and discovering yet unknown environmental influences (sudden temperature changes, exposure to cold) in the pathogenesis of common or unrecognized infections.

\section{References}

1. Salerian AJ (2017) Human body may produce bacteria. Medical Hypotheses 103: 31-132.

2. Salerian AJ (2018) Was Pasteur Wrong? Human Cells may Generate Bacteria. Biomed J Sci \&Tech Res 4(5).

3. Schopf JW (2006) Fossil evidence of Arcaean Life. philosophical transactions of the Royal Society biological sciences 361(1470): 869-885.

4. Cavalier-Smith T (2006) Cell evolution and Earth history: Stasis and revolution. Philosophical transactions Royal Society in London biological sciences 361(1470): 969-1006.

5. Altermann W, Kazmieczak J (2003) Archean Micro fossils: A reappraisal of early life on earth. Researching microbiology 154(9): 611-617.
6. Lazcano A, Bada JL (2003) Orig Life Evol Biosph 33: 235.

7. Rosenow EC (1914) Test mutations within the streptococcus enamel proper school. Journal of Infectious Disorders 14(1): 1-32.

8. Bracco RM, Krauss MR, Roe AS, MacLeod CM (1957) Transformation reactions between pneumococcus and three strains of streptococci. J Exp Med 106(2): 247-259.

9. Krause DS, Thiese ND, Collector ML (2001) Multi-Organ, Multi-Lineage Engraftment by a Single Bone Marrow-Derived Stem Cell. Cell 105(3): 369377.

10. Brown P, Will RG, Bradley R, Asher DM, Detwiler L (2001) Bovine spongiform encephalopathy and variant Creutzfeldt- Jacob disease: Background evolution and current concerns. Emerging Infectious Diseases 7(1): 6-16.

11. Jimenez E, Marin ML, Matin R, Odriozola J, M Olivares, et al. (2008) Is fetal meconium sterile? Research in Microbiology 159(3): 187-189.

12. Ardissone AN, DeLa Cruz D, Davis- Richardson AG, Rechigi KT (2014) Meconium microbiome analysis identifies bacteria correlated with premature birth. PLOS ONE 9(6): e101399.

13. Cabrera -Rubio R, Collado MC, Latinen K, Salminnen S, Isolauri E, et al. (2012) The human milk microbiome changes over lactation and is shaped by maternal weights mode of delivery. The American Journal of clinical nutrition 96(3): 544-551.

14. Martin R, Langa S, Reviriego C, Jimenez E, Marin ML, et al. (2003) Milk is a source of lactic acid bacteria for the infant gut. The journal of pediatrics 143(6): 754-758.

15. Hafez Ma, El-Shamy SB (1985) Genetic Susceptibility in Pityriasis versicolor. Dermatologica 171(2): 86-88.

16. Burke R (1961) Tinea Versicolor: Susceptibility factors in experimental infection in human beings. Journal of investigative dermatology 36(5): 389-401.

17. Faergemann J, Fredricksson T (1981) Experimental infections in rabbits and humans with Pityrosprum orbiculare and P.ovale. Journal of Investigative Dermatology 77(3): 314-318. 
18. Faergemann J, Aly R, Wilson DR, Maibach HI (1983) Skin occlusion: Effect on Pityrosprum orbiculare, skinP-CO2, ph, trans epidermal water loss, and water content. Archives of dermatological research November 275(6): 383-387.

19. Najm WI (2011) Peptic ulcer disorder. Primary care 38(3): 383-394.

20. Macedo JLS, Santos JB (2005) Bacterial and fungal colonization of burn wounds. Mem Inst Oswaldo Cruz 100(5): 535-539.

21. Kaur H, Bhat J, Anvikar AR, Rao S, Gadge V (2006) Bacterial profile of blood and burn wound infections in burn patients. Burns 34: 89-95.

ISSN: 2574-1241

DOI: 10.26717/BJSTR.2018.09.001739

Alen J Salerian MD. Biomed J Sci \& Tech Res

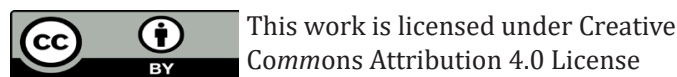

Submission Link: https://biomedres.us/submit-manuscript.php
22. Dib JR, Weiss A, Neumann A, Ordonez O, Estevez M, et al. (2009) Isolation of bacteria from remote high-altitude Andean Lakes Able to grow in the presence of antibiotics. Recent patents ion Anti-infective drug discovery 4(1): 66-76.

23. Darwin C, Barlow N (1887) The autobiography of Charles Darwin. New York: Norton, USA

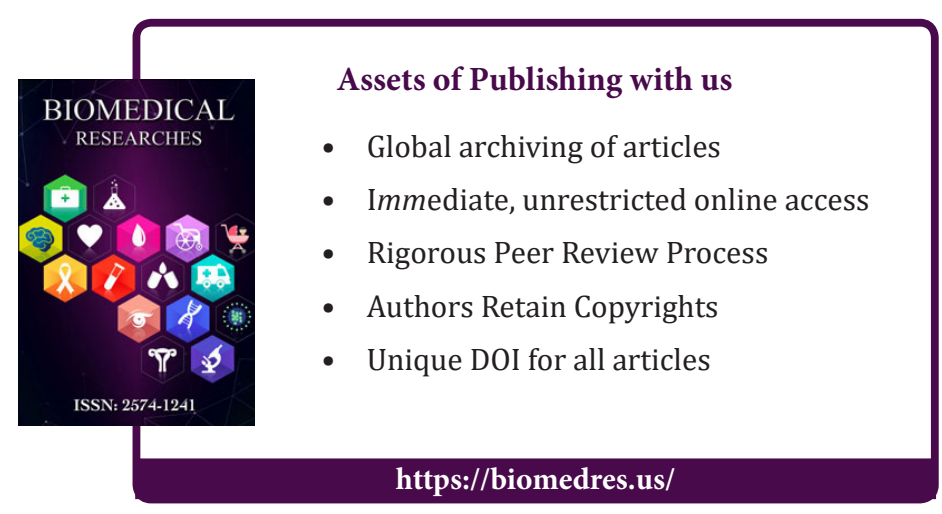

